\title{
Anti-infective efficacy of Psidium guajava L. leaves against
}

\section{certain pathogenic bacteria [version 1; peer review: 1}

\section{approved, 1 approved with reservations]}

\author{
Pooja Patel(D1, Chinmayi Joshi(D1, Tannaz Birdi2, Vijay Kothari(i)1 \\ ${ }^{1}$ Institute of Science, Nirma University, Ahmedabad, Gujarat, 382481, India \\ ${ }^{2}$ Foundation for Medical Research, Mumbai, India
}

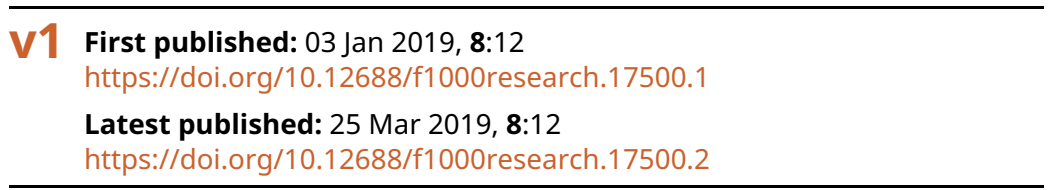

\section{Abstract}

Water extracts of Psidium guajava leaves prepared by three different extraction methods were compared with respect to their anti-infective activity against Pseudomonas aeruginosa and Staphylococcus aureus in the nematode host Caenorhabditis elegans. The water extract prepared by Microwave Assisted Extraction method was found to have better anti-infective activity, and its activity was further compared with hydroalcoholic extract prepared using the same extraction method against five different pathogenic bacteria. Both these extracts could attenuate virulence of $P$. aeruginosa, $S$. aureus, Serratia marcescens, and Chromobacterium violaceum, towards C. elegans. Anti-infective efficacy of $P$. guajava leaf extract seems partly to stem from its quorummodulatory property, as it could modulate production of quorum sensing-regulated pigments in all the susceptible bacteria.

\section{Keywords}

Guava leaf, Microwave Assisted Extraction (MAE), Caenorhabditis elegans, Quorum Sensing (QS), Antimicrobial Resistance (AMR), Antivirulence

Open Peer Review
Approval Status
version 2
(revision)
03 Jan 2019
.............................................................................
1. Virupakshi Soppina (ID), Indian Institute of
Technology Gandhinagar, Gandhinagar, India
2. Vivekananda Mandal, Guru Ghasidas
Central University, Bilaspur, India
Any reports and responses or comments on the
article can be found at the end of the article.


Corresponding author: Vijay Kothari (vijay.kothari@nirmauni.ac.in)

Author roles: Patel P: Investigation, Writing - Original Draft Preparation; Joshi C: Investigation; Birdi T: Conceptualization, Funding Acquisition, Writing - Review \& Editing; Kothari V: Conceptualization, Formal Analysis, Funding Acquisition, Methodology, Supervision, Visualization, Writing - Original Draft Preparation, Writing - Review \& Editing

Competing interests: No competing interests were disclosed.

Grant information: The author(s) declared that no grants were involved in supporting this work.

Copyright: @ 2019 Patel P et al. This is an open access article distributed under the terms of the Creative Commons Attribution License, which permits unrestricted use, distribution, and reproduction in any medium, provided the original work is properly cited. Data associated with the article are available under the terms of the Creative Commons Zero "No rights reserved" data waiver (CC0 1.0 Public domain dedication).

How to cite this article: Patel P, Joshi C, Birdi T and Kothari V. Anti-infective efficacy of Psidium guajava L. leaves against certain pathogenic bacteria [version 1; peer review: 1 approved, 1 approved with reservations] F1000Research 2019, 8:12 https://doi.org/10.12688/f1000research.17500.1

First published: 03 Jan 2019, 8:12 https://doi.org/10.12688/f1000research.17500.1 


\section{Introduction}

Given the heavy global burden of infectious diseases, it is imperative to discover novel pharmaceutical assets for combating antimicrobial resistance, with particular focus on antibioticresistant bacterial pathogens recently listed by the World Health Organization as of high/ critical priority (Tacconelli et al., 2018). Since the antibiotic pipeline lacks new mechanisms against resistant bacteria, particularly gram-negative bacteria (see here for more information), it is necessary to look for new antibiotics as well as non-antibiotic approaches to tackle bacterial infections.

A reverse pharmacology approach (Raut et al., 2017) of investigating plant extracts, particularly those employed in documented or folklore traditional medicine, for their potential anti-pathogenic efficacy may pave the way for discovery and development of novel antimicrobial molecules/ formulations. We undertook the current study to investigate anti-infective potential of one such plant extract, Psidium guajava L. (common name- guava; Family- Myrtaceae) leaf extract, against five different pathogenic bacteria. This plant has traditionally been used for treatment of various gastrointestinal problems including diarrhea and dysentery (Birdi et al., 2010), which are caused usually due to microbial infections.

\section{Methods}

Plant material

Shade dried mature guava leaves of Sardar variety, one of the five common Indian varieties were used. The leaves were collected in September 2014 from Shirwal, Satara district, Maharashtra, India. The dried leaves were stored in a sealed plastic bag at $25^{\circ} \mathrm{C}$. A voucher specimen was deposited at Naoroji Godrej Centre for Plant Research (NGCPR, Shirwal) under herbarium number NGCPR 712.

\section{Test pathogens}

Pathogenic bacteria used in this study (Dataset 1: Extended data) included Staphylococcus aureus (MTCC 737); beta-lactamase producing multidrug resistant strains of Chromobacterium violaceum (MTCC 2656) and Serratia marcescens (MTCC 97); multidrug resistant Pseudomonas aeruginosa; and Streptococcus pyogenes (MTCC 1924). Resistance to three or more antibiotics during antibiotic susceptibility profiling (Dataset 1) was taken as the criteria for tagging any organism as 'multidrug resistant'. P. aeruginosa was sourced from our internal culture collection. All other cultures were procured from MTCC (Microbial Type Culture Collection, Chandigarh, India).

\section{Extraction}

In order to identify the best possible extraction method with respect to the desired biological activity, we extracted the powder of the dried leaves in water using three different extraction methods: Decoction, Microwave Assisted Extraction (MAE), and Vacuum Assisted Extraction (VAE). Protocols employed for each extraction method are described below:

\section{Decoction}

Decoction of guava leaves was prepared in accordance to the traditional method described in the Ayurvedic texts (Thakkur, 1979). $1 \mathrm{~g}$ of the plant material was boiled in $16 \mathrm{~mL}$ double distilled water, till the volume was reduced to $4 \mathrm{~mL}$.

\section{Microwave Assisted Extraction (MAE) (Kothari et al., 2009)}

$1 \mathrm{~g}$ of leaf powder was soaked into $16 \mathrm{~mL}$ of water or $50 \%$ ethanol, and subjected to microwave heating (Electrolux EM30EC90SS) at $720 \mathrm{~W}$. Total extraction duration was $140 \mathrm{~s}$, of which first heating was for $40 \mathrm{~s}$, and subsequent two heating cycles of 10 $\mathrm{s}$ each. Intermittent cooling period between any two heating cycles was kept $40 \mathrm{~s}$. Liquid volume at the end of extraction was $4 \mathrm{~mL}$.

Vacuum Assisted Extraction (VAE) (Wang et al., 2014) $1 \mathrm{~g}$ of dry leaf powder was mixed with $16 \mathrm{~mL}$ of water. Vacuum pump (MEDICA INSTRUMENT Mfg. Co.) was attached to the vessel containing plant material and solvent, and the working pressure was set at 7.36 psi (15 In. $\mathrm{Hg}$ ). Total duration of heating was $20 \mathrm{~min}$, of which for $15 \mathrm{~min}$ the system was at $65^{\circ} \mathrm{C}$ (at which boiling started). Extraction was stopped when liquid volume was reduced to $4 \mathrm{~mL}$.

Extraction performed by methods described above, was followed by macro-filtration using nylon strainer followed by centrifugation (at 10,000 rpm for $15 \mathrm{~min}$; Remi BZCI-8729), and filtration with Whatman paper \# 1 (Axiva, Haryana). After this filtration, solvent was evaporated from the extract. For bioassay, extracts was reconstituted in absolute DMSO (Merck, Mumbai). Reconstituted extracts were collected in sterile flat bottom glass vials (15 mL, Merck, Mumbai) covered with aluminum foil, and protected from light to avoid photo-oxidation of light-sensitive compounds. The internal surface of vial cap was also wrapped with aluminum foil to avoid leaching of vial cap material (Houghton \& Raman, 1998). Reconstituted extract was stored under refrigeration for further use. Extraction efficiency was calculated as percentage weight of the starting dried plant material.

Extraction efficiency obtained with these methods was $6.30 \%$, $5.80 \%$, and $6.0 \%$ respectively. All the extracts were reconstituted in dimethylsulfoxide (DMSO, Merck) upon drying, and stored under refrigeration $\left(4-8^{\circ} \mathrm{C}\right)$ till further use.

In vivo efficacy of these water extracts against Pseudomonas aeruginosa, and Staphylococcus aureus was tested in the nematode host Caenorhabditis elegans, wherein the extract prepared by MAE had better anti-infective activity. Therefore, the extract prepared by MAE was compared with its hydroalcoholic extract prepared using the same method. Extraction efficiency obtained for the latter case was $2.0 \%$.

In vivo assay for anti-infective activity

In vivo efficacy of the guava leaf extract (GLE) was evaluated using the nematode worm Caenorhabditis elegans as the model 
host, employing the method described by Eng \& Nathan, (2015) with some modification. C. elegans was maintained on Nematode Growing Medium (NGM) which consisted of $3 \mathrm{~g} / \mathrm{L} \mathrm{NaCl}$, $2.5 \mathrm{~g} / \mathrm{L}$ peptone, $1 \mathrm{M} \mathrm{CaCl}_{2}, 1 \mathrm{M} \mathrm{MgSO}_{4}, 5 \mathrm{mg} / \mathrm{mL}$ cholesterol, 1 $\mathrm{M}$ phosphate buffer of $\mathrm{pH} 6,17 \mathrm{~g} / \mathrm{L}$ agar-agar with $E$. coli OP50 (procured from LabTIE B.V., JR Rosmalen, the Netherlands) as the feed. The worm population to be used for the in vivo assay was kept on NGM plates not seeded with E. coli OP50 for three days, before being challenged with the test pathogen.

Pathogenic bacteria was incubated with GLE for 22-24h (48 $\mathrm{h}$ in case of $S$. marcescens and $S$. aureus) at $37^{\circ} \mathrm{C}\left(28^{\circ} \mathrm{C}\right.$ for S. marcescens). Following incubation, $\mathrm{OD}_{764}$ of the culture suspension was equalized to that of the DMSO control. $100 \mu \mathrm{L}$ of this bacterial suspension was mixed with $900 \mu \mathrm{L}$ of the M9 buffer containing 10 worms (L3-L4 stage). This experiment was performed in 24-well (sterile, non-treated) polystyrene plates (HiMediaTPG24), and incubation was carried out at $22^{\circ} \mathrm{C}$. Number of live vs. lead worms was counted daily for five days by putting the plate (with lid) under light microscope (4X). Standard antibiotic- and catechin- treated bacterial suspension were used as positive control. Straight worms were considered to be dead, Plates were gently tapped to confirm lack of movement in the dead-looking worms. On the last day of the experiment, when plates could be opened, their death was reconfirmed by touching them with a straight wire, wherein no movement was taken as confirmation of death.

\section{Statistical analysis}

Values reported are means of four independent experiments, whose statistical significance was assessed using $t$-test performed through Microsoft Excel (2013). $P$ values $\leq 0.05$ were considered to be statistically significant.

\section{Results}

GLE prepared by three different methods were compared, at three different concentrations, for their anti-infective activity against $P$. aeruginosa and $S$. aureus (Figure 1; Dataset 1: Underlying data). At $50 \mu \mathrm{g} / \mathrm{mL}$, GLE prepared by MAE proved superior to that prepared by decoction or VAE method, with respect to its ability to attenuate $P$. aeruginosa's virulence towards C. elegans. At $0.5 \mu \mathrm{g} / \mathrm{mL}$, extract prepared by decoction method registered least activity against this bacterium. At the same concentration, against $S$. aureus, extract prepared by VAE displayed the least activity. Based on these results, we concluded MAE as a better extraction method, and then extracted guava leaves using this method in water as well as water:alcohol (1:1) mixture. Both of these extracts prepared using MAE were then assayed for their anti-infective potential against five different pathogenic bacteria.

Both water as well as the hydroalcoholic extract of guava leaves could attenuate virulence of all the test pathogens (except $S$. pyogenes) towards $C$. elegans (Figure 2; Dataset 1: Underlying data). Both these extracts exhibited statistically similar anti-pathogenic efficacy against all susceptible bacteria, but the hydroalcoholic extract exhibited $10-15 \%$ better activity against $S$. aureus than the water extract. Despite the lowest extraction yield among all extracts reported in this study, the hydroalcoholic GLE was found to possess the highest (at par with water extract against all gram-negative pathogens) anti-pathogenic activity. Critical importance of choice of most appropriate extraction method and solvent for preparation of bioactive extracts has earlier been also emphasized by us (Gupta et al., 2012; Kothari et al., 2012), and others (Ngo et al., 2017; Sasidharan et al., 2011).

To have some insight into the mode of action of GLE, we incubated all the five test bacteria with GLE to investigate whether it affects bacterial growth and/or quorum-sensing (QS) regulated pigment production (a marker trait). Bacterial cell density and pigment production were quantified as earlier described by us (Joshi et al., 2016; Patel et al., 2018). At least one concentration of GLE was found to modulate pigment production in all the four pigmented bacteria (Figure 3; Dataset 1: Underlying data). This extract did not inhibit bacterial growth heavily, and hence can be expected to exert lesser selection pressure on susceptible bacterial populations.

Details of organisms used in this study including antibiogram

https://dx.doi.org/10.5256/f1000research.17500.d230521

Raw data for Figures 1-3 showing the anti-infective efficacy of Psidium guajava L. leaves against pathogenic bacteria

https://dx.doi.org/10.5256/f1000research.17500.d230522

\section{Conclusion}

Results of the present study validate the traditional use of guava leaves for medicinal purposes and suggests one of the possible mechanisms through which it exerts its anti-infective activity, i.e. its ability to interfere with the bacterial QS machinery. Further investigation regarding GLE's effect on pathogenic bacteria at the whole transcriptome level is warranted to unravel the molecular mechanisms underlying its anti-pathogenic efficacy. 


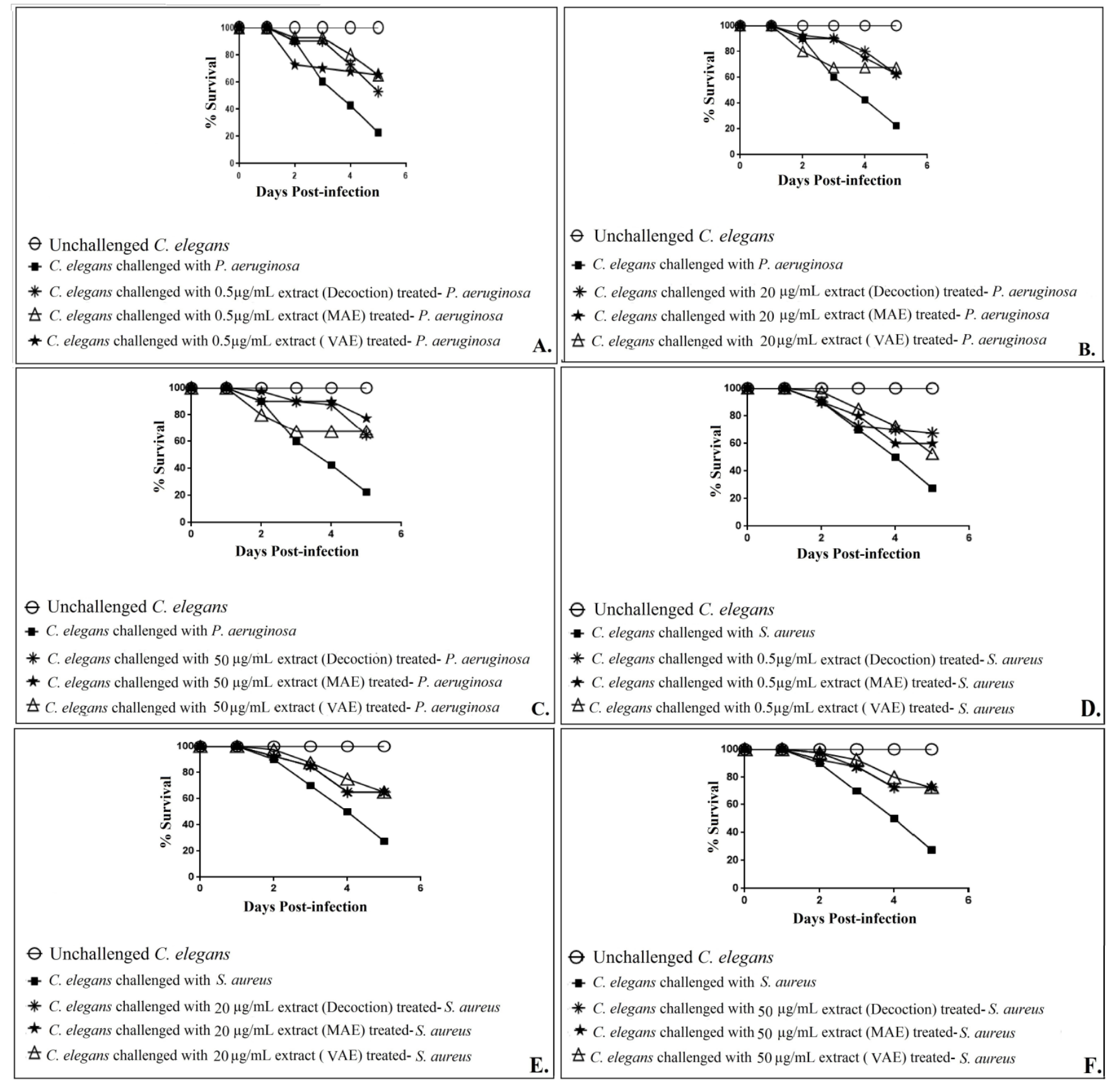

Figure 1. Comparison of in vivo anti-infective efficacy of $P$. guajava leaf extracts prepared by three different extraction methods, against $P$. aeruginosa $(\mathbf{A}-\mathbf{C})$, and S. aureus (D-F). Catechin $(50 \mu \mathrm{g} / \mathrm{mL})$ and gentamicin $(0.1 \mu \mathrm{g} / \mathrm{mL})$ employed as positive controls conferred $100 \%$ and $80 \%$ protection on the worm population, respectively. DMSO present in the 'vehicle control' at $0.5 \% \mathrm{v} / \mathrm{v}$ did not affect virulence of the bacterium towards $C$. elegans. DMSO $(0.5 \% \mathrm{v} / \mathrm{V})$ and GLE at tested concentrations showed no toxicity towards $C$. elegans. MAE: Microwave Assisted Extraction; VAE: Vacuum Assisted Extraction; GLE: Guava Leaf Extract 


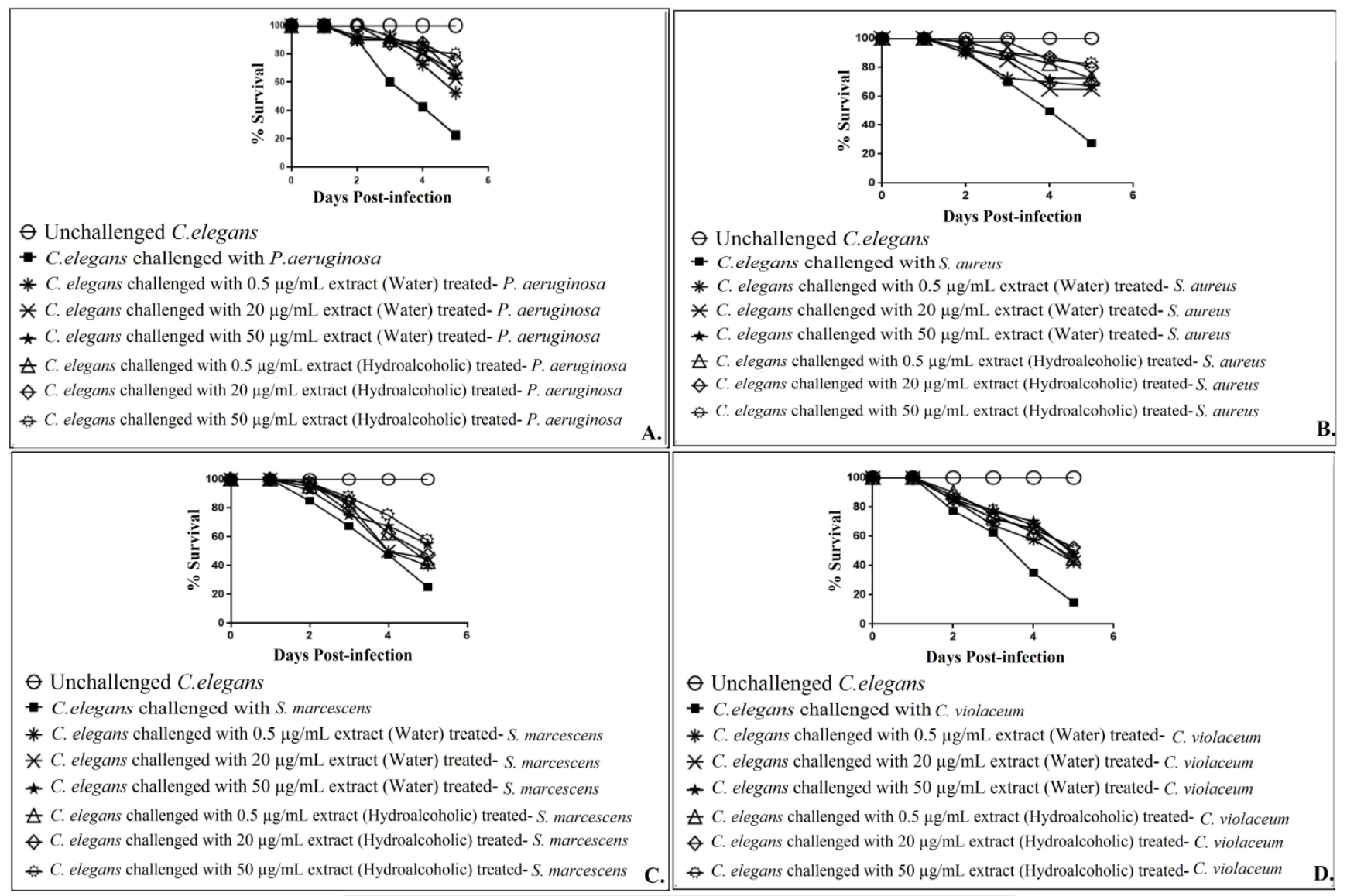

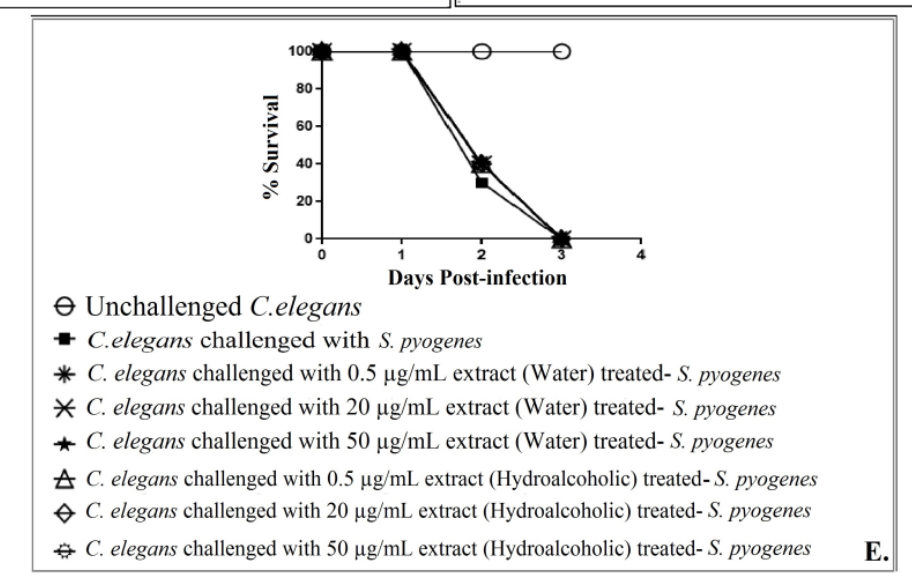

Figure 2. Comparison of the in vivo anti-infective potential of water extract and hydroalcoholic extract of $P$. guajava leaf extracts prepared by Microwave Assisted Extraction method, against five different pathogenic bacteria. Figures A-E shows data against P. aeruginosa, S. aureus, S. marcescens, C. violaceum and S. pyogenes respectively. Catechin $(50 \mu \mathrm{g} / \mathrm{mL})$ employed as a positive control conferred $100 \%$ protection on worm population against all the pathogenic bacteria except $S$. pyogenes. Against $S$. pyogenes, catechin could not offer any protection to host worms. Gentamicin $(0.1 \mu \mathrm{g} / \mathrm{mL})$ allowed survival of worm population to the extent of $80 \%$ in face of P. aeruginosa, S. aureus, or S. pyogenes challenge; and 100\% against the remaining two pathogens. DMSO present in the 'vehicle control' at $0.5 \% \mathrm{v} / \mathrm{v}$ did not affect virulence of the bacteria towards $C$. elegans. DMSO $(0.5 \% \mathrm{v} / \mathrm{v})$ and GLE at tested concentrations showed no toxicity towards $C$. elegans. 


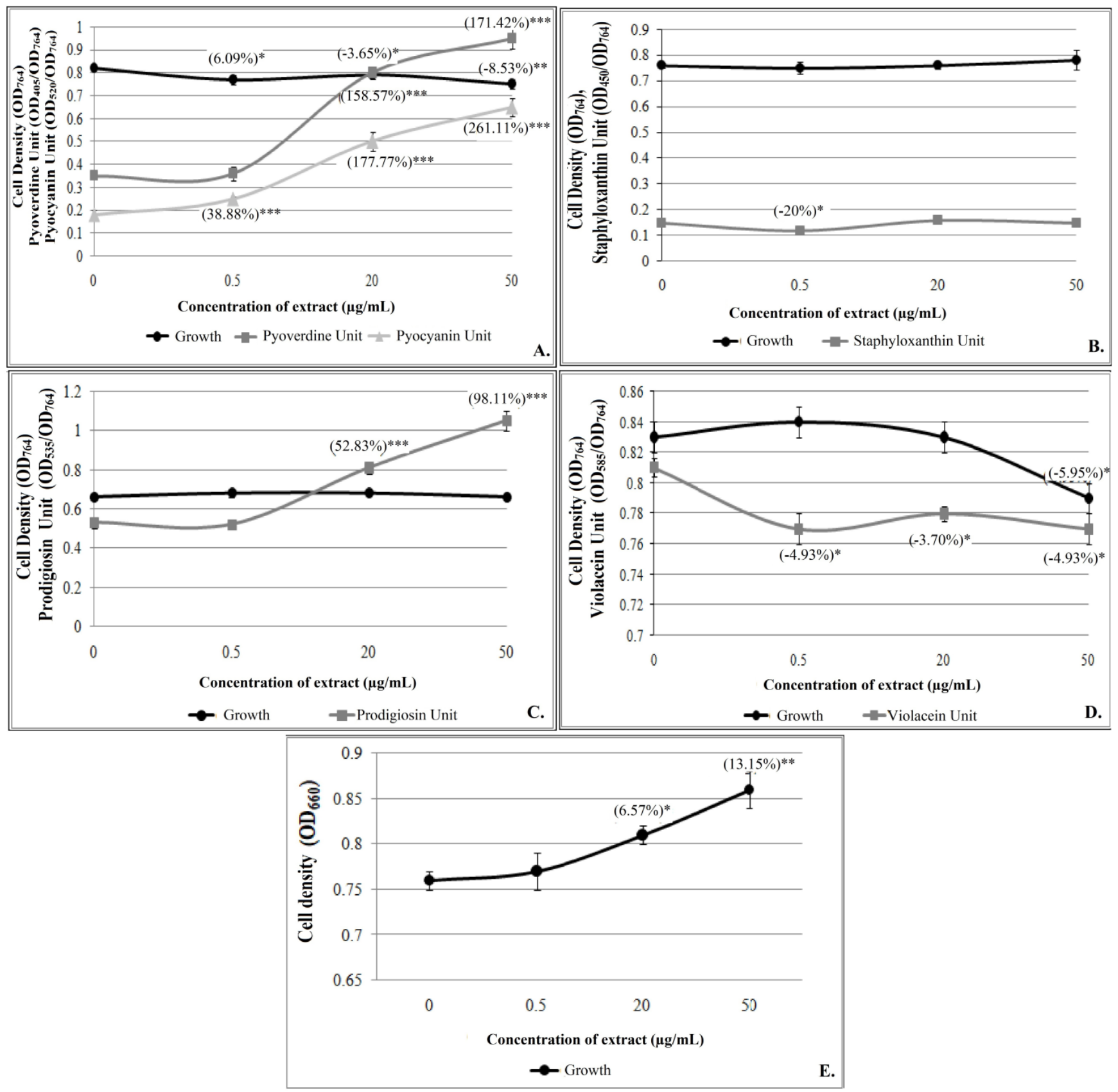

Figure 3. Effect of hydroalcoholic extract of $P$. guajava leaves prepared by Microwave Assisted Extraction method on bacterial growth and QS-regulated pigment production. (A) P. aeruginosa (B) S. aureus (C) S. marcescens (D) C. violaceum (E) S. pyogenes. Bacterial cell density and pigment production were quantified as earlier described by us (Joshi et al., 2016). Bacterial growth was measured as $\mathrm{OD}_{764}$ for the four pigmented bacteria, while for $S$. pyogenes $\mathrm{OD}_{660}$ was used. OD of pyoverdine was measured at $405 \mathrm{~nm}$, and that of pyocyanin at 520 $\mathrm{nm}$; Pyoverdine Unit was calculated as the ratio $\mathrm{OD}_{405} / \mathrm{OD}_{764}$ (an indication of pyoverdine production per unit of growth); Pyocyanin Unit was calculated as the ratio $\mathrm{OD}_{520} / \mathrm{OD}_{764}$ (an indication of pyocyanin production per unit of growth. $\mathrm{OD}$ of staphyloxanthin was measured at 450 $\mathrm{nm}$, and Staphyloxanthin Unit was calculated as the ratio $\mathrm{OD}_{450} / \mathrm{OD}_{764}$ (an indication of staphyloxanthin production per unit of growth). OD of prodigiosin was measured at $535 \mathrm{~nm}$, and Prodigiosin Unit was calculated as the ratio $\mathrm{OD}_{535} / \mathrm{OD}_{764}$ (an indication of prodigiosin production per unit of growth). OD of violacein was measured at $585 \mathrm{~nm}$, and Violacein Unit was calculated as the ratio $O D_{585} / O D_{764}$ (an indication of violacein production per unit of growth). QS: Quorum sensing 
Data availability

Underlying data

F1000Research: Raw data for Figure 1-Figure 3 showing the anti-infective efficacy of Psidium guajava $\mathrm{L}$. leaves against pathogenic bacteria., https://doi.org/10.5256/f1000research. 17500 . d230522 (Patel et al., 2018a).

\section{Extended data}

F1000Research: Details of organisms used in this study including antibiogram., https://doi.org/10.5256/f1000research.17500. d230521 (Patel et al., 2018b).
Grant information

The authors declare that no grants were involved in supporting this work.

Acknowledgements

Authors thank Nirma Education and Research Foundation (NERF), Ahmedabad for financial and infrastructural support.
Birdi T, Daswani P, Brijesh S, et al.: Newer insights into the mechanism of action of Psidium guajava L. leaves in infectious diarrhoea. BMC Complement Altern Med. 2010; 10(1): 33

PubMed Abstract | Publisher Full Text | Free Full Text

Eng SA, Nathan S: Curcumin rescues Caenorhabditis elegans from a Burkholderia pseudomallei infection. Front Microbiol. 2015; 6: 290. PubMed Abstract | Publisher Full Text | Free Full Text

Gupta A, Naraniwal M, Kothari V: Modern extraction methods for preparation of bioactive plant extracts. International Journal of Applied and Natural Sciences. 2012; 1(1): 8-26.

Reference Source

Houghton P, Raman A: Laboratory Handbook for the Fractionation of Natural Extracts. Chapman and Hall: London, UK. 2016; 18.

Joshi C, Kothari V, Patel P: Importance of selecting appropriate wavelength, while quantifying growth and production of quorum sensing regulated

pigments in bacteria. Recent Pat Biotechnol. 2016; 10(2): 145-152.

PubMed Abstract | Publisher Full Text

Kothari V, Gupta A, Naraniwal M: Comparative study of various methods for extraction of antioxidant and antibacterial compounds from plant seeds. Journal of Natural Remedies. 2012; 12(2): 162-173.

Reference Source

Kothari V, Punjabi A, Gupta S: Optimization of microwave-assisted extraction of Annona squamosa seeds. The Icfai University Journal of Life Sciences. 2009; 3(1): 55-60.

Reference Source

Ngo TV, Scarlett CJ, Bowyer MC, et al.: Impact of different extraction solvents on bioactive compounds and antioxidant capacity from the root of Salacia chinensis. L. J Food Quality. 2017; 2017.

Publisher Full Tex
Patel P, Joshi C, Palep H, et al:: Anti-infective potential of a quorum modulatory polyherbal extract (Panchvalkal) against certain pathogenic bacteria. J Ayurveda Integr Med. 2018.

Publisher Full Text

Patel P, Joshi C, Birdi T, et al:: Anti-infective efficacy of Psidium guajava L. leaves against certain pathogenic bacteria. F1000Research. 2018a. https://www.doi.org/10.5256/f1000research.17500.d230522.

Patel P, Joshi C, Birdi T, et al.: Anti-infective efficacy of Psidium guajava L. leaves against certain pathogenic bacteria. F1000Research. 2018b. https://www.doi.org/10.5256/f1000research.17500.d230521

Raut AA, Chorghade MS, Vaidya ADB: Reverse Pharmacology. In: Innovative Approaches in Drug Discovery (Eds: Patwardhan B and Chaguturu R). 2017; 89-126.

Publisher Full Text

Sasidharan S, Chen Y, Saravanan D, et al.: Extraction, isolation and characterization of bioactive compounds from plants' extracts. Afr J Tradit Complement Altern Med. 2011; 8(1): 1-10.

PubMed Abstract | Publisher Full Text | Free Full Text

Tacconelli E, Carrara E, Savoldi A, et al:: Discovery, research, and development of new antibiotics: the WHO priority list of antibiotic-resistant bacteria and tuberculosis. Lancet Infect Dis. 2018; 18(3): 318-327.

PubMed Abstract | Publisher Full Text

Thakkur CG: Introduction to ayurveda: Basic Indian medicine. Jamnagar: Gulakunverba Ayurvedic Society, 1976; 2.

Wang YQ, Wu ZF, Ke G, et al:: An effective vacuum assisted extraction method for the optimization of labdane diterpenoids from Andrographis paniculata by response surface methodology. Molecules. 2014; 20(1): 430-45.

PubMed Abstract | Publisher Full Text 


\section{Open Peer Review}

\section{Current Peer Review Status:}

\section{Version 1}

Reviewer Report 25 February 2019

https://doi.org/10.5256/f1000research.19139.r42508

(C) 2019 Mandal V. This is an open access peer review report distributed under the terms of the Creative Commons Attribution License, which permits unrestricted use, distribution, and reproduction in any medium, provided the original work is properly cited.

\section{Vivekananda Mandal}

Institute of Pharmacy, Guru Ghasidas Central University, Bilaspur, Chhattisgarh, India

In this short study, the authors have studied anti-pathogenic potential of $P$. gujava leaves, which is an important plant in traditional medicine. It is good to see that among test bacteria, authors have included multi-drug resistant/beta-lactamase producing gram-negative bacteria, as it is difficult to find 'hits' against gram-negative bacteria in general. Their idea of comparing the same leaf extract prepared using different extraction methods also seems to be logical, as choice of the most appropriate extraction method is very much crucial while assessing the biological activity of plant extracts. It can have a significant bearing on the final results.

They have found MAE to be a good method. MAE has earlier been also reported by various groups to be an efficient extraction method, particularly for fast extraction of plant phenolic compounds. Further, they have used the worm $C$. elegans as the model host for their test pathogens. This worm is a good choice for generating useful preliminary data on in vivo efficacy of potential antipathogenic extracts/ formulations.

In the case of some bacteria like $P$. aeruginosa, there is an overlap among virulence factors (e.g. pyocyanin) responsible for damaging the human cells and those killing the worm. They have also compared the GLE prepared in water vs. that prepared in water + alcohol, and have emphasized the importance of choice of most appropriate extraction method and solvent for preparation of bioactive extracts.

Their in vitro experiments have provided a good clue on one of the possible ways regarding mode of action of GLE i.e. QS interference. QS in recent years has been reported by many research groups to be a target worth pursuing, in search of novel antimicrobials. Raw data submitted by the authors also seem to be in good shape, and in line with their findings reported in main text.

Overall, this seems to be an okay study, and can be approved for indexing without any major changes. However, in future the authors should try to come up with a full-length report describing molecular mechanisms at the genome/transcriptome level explaining the mechanistic basis of GLE's anti-pathogenic efficacy. 
Is the work clearly and accurately presented and does it cite the current literature? Yes

Is the study design appropriate and is the work technically sound?

Yes

Are sufficient details of methods and analysis provided to allow replication by others?

Yes

If applicable, is the statistical analysis and its interpretation appropriate?

Yes

Are all the source data underlying the results available to ensure full reproducibility? Yes

Are the conclusions drawn adequately supported by the results?

Yes

Competing Interests: No competing interests were disclosed.

Reviewer Expertise: ethnopharmacology, extraction and purification of natural products

I confirm that I have read this submission and believe that I have an appropriate level of expertise to confirm that it is of an acceptable scientific standard.

Reviewer Report 21 January 2019

https://doi.org/10.5256/f1000research.19139.r42519

(C) 2019 Soppina V. This is an open access peer review report distributed under the terms of the Creative Commons Attribution License, which permits unrestricted use, distribution, and reproduction in any medium, provided the original work is properly cited.

\section{Virupakshi Soppina}

Indian Institute of Technology Gandhinagar, Gandhinagar, Gujarat, India

Patel et al. study the anti-infective properties of Psidium guajava leaf extract, against five different pathogenic bacteria. They use $C$. elegans as a model system to study the anti-infective efficiency of $P$. guajava leaf extract formulated from three different extraction methods. Overall this is an exciting paper, validates the traditional use of guava leaves for medicinal purposes and also a possible mechanism. The topic is important, and this paper adds something new to the pharmacology field.

The key finding of this study is that the water and hydroalcoholic extracts prepared using microwave-assisted extraction method could successfully attenuate the virulence of different 
pathogenic bacteria and also exhibit anti-infective property towards C. elegans. I do not have any significant concerns or comments on the manuscript. However, there are some minor comments to improve the manuscript readability and understand the experiments.

1. The manuscript needs a more relevant background to understand the significance of the manuscript.

2. It would be useful to state why the authors have specifically used three extraction methods that are used in the paper over several extraction methods available in the field.

3. Under In vivo assay for anti-infective activity section, the sentence 'Pathogenic bacteria were incubated with GLE for $22-24 \mathrm{~h}$ (48h in case of S. marcescens and S. aureus) at $37^{\circ} \mathrm{C}\left(28^{\circ} \mathrm{C}\right.$ for S. marcescens). Following incubation, OD764 of the culture suspension was equalized to that of the DMSO control.' is highly confusing so please rewrite with precise details.

4. The sentence 'Number of live vs. lead worms was counted daily for five days by putting the plate' should be written as 'Number of live vs. dead worms was counted daily for five days by putting the plate.'

5. In Figure 1B, please use consistent symbol shapes for each data set.

6. Graphs in Figure 2 are too small and crowded (it is difficult to appreciate the results), so please consider increasing the size of graphs or using different symbol shapes or think of presenting the data in bar graph format.

7. Please include the data for positive controls [catechin $(50 \mu \mathrm{g} / \mathrm{mL})$ and gentamicin $(0.1 \mu$ $\mathrm{g} / \mathrm{mL}$ )] in Figure 1 and 2.

8. Please provide scientific background for using catechin and gentamicin as positive controls.

9. The sentence 'At least one concentration of GLE was found to modulate pigment production in all the four pigmented bacteria (Figure 3; Dataset 1: Underlying data). This extract did not inhibit bacterial growth heavily, and hence can be expected to exert lesser selection pressure on susceptible bacterial populations.' is difficult to understand so please consider rewriting with clear statements.

10. The results of Figure 3 need more discussion in further details in the context of published literature.

Is the work clearly and accurately presented and does it cite the current literature? Yes

Is the study design appropriate and is the work technically sound?

Partly

Are sufficient details of methods and analysis provided to allow replication by others? Partly

If applicable, is the statistical analysis and its interpretation appropriate? Yes

Are all the source data underlying the results available to ensure full reproducibility? Partly

Are the conclusions drawn adequately supported by the results? Partly 
Competing Interests: No competing interests were disclosed.

Reviewer Expertise: Cell and molecular biology, biochemistry, C. elegans, biophysics, fluorescent microscopy, genetics

\section{I confirm that I have read this submission and believe that I have an appropriate level of expertise to confirm that it is of an acceptable scientific standard, however I have significant reservations, as outlined above.}

Author Response 16 Mar 2019

Vijay Kothari, Nirma University, Ahmedabad, India

We thank both the referees for devoting their time in reviewing our manuscript. Our comment-wise response to referee-1's comments is as under:

Comment 1: A line has been added in 'Introduction' telling the significance of such studies aimed at validating the traditional medicine claims.

Comment 2: Basis of selection of these three extraction method has been added in the 'Methods' section under subheading 'Extraction'.

Comments 3,4, and 9: Sentences have been rewritten to correct spelling mistake, and add clarity.

Comment 5: Error regarding symbol shape has been corrected in the revised version of Figure-1.

Comment 6: To avoid the crowded appearance of Figure-2, in the revised version, we have divided all the five parts A-E into two separate graphs, one for water extract, and another for hydroalcoholic extract.

Comment 7: Data for positive controls has already been there in legends of Figure 12. Adding separate lines for them in graph will again make the figures crowded. Comment 8: Scientific background for selection of positive controls has been added under the heading "In vivo assay for anti-infective activity".

Comment 10: Relevant content has been added discussing the results of Figure-3, citing appropriate references.

Since this is a short 'Research Note', we have focused more on presenting our results, and refrained from adding too much content for 'Discussion'.

Competing Interests: None 
The benefits of publishing with F1000Research:

- Your article is published within days, with no editorial bias

- You can publish traditional articles, null/negative results, case reports, data notes and more

- The peer review process is transparent and collaborative

- Your article is indexed in PubMed after passing peer review

- Dedicated customer support at every stage

For pre-submission enquiries, contact research@f1000.com 